\title{
LEGAL RIGHTS OF CONSUMER FINANCE AGREEMENT RELATED TO FIDUSIAN GUARANTEE SETTINGS IN THE CITY OF GORONTALO
}

\author{
Nur Insani and Upik Mutiara
}

\author{
Universitas Ichsan Gorontalo \\ Universitas Muhammadiyah Tangerang, \\ Magister Hukum \\ Jl. Raden Saleh No. 17, Kota Gorontalo, Provinsi Gorontalo, 091033 \\ Jalan Perintis Kemerdekaan I Babakan No.33, RT.007/RW.003, Cikokol, Kec. Tangerang, Kota \\ Tangerang, Banten 15118 \\ Correspondence Email : dhinilaw@gmail.com
}

\begin{abstract}
This study aims to determine the implementation of fiduciary guarantees in financing agreements for motor vehicle purchases and the legal consequences if debtors default in financing the purchase of motor vehicles with fiduciary guarantees at PT. BFI Finance Gorontalo. The research method uses normative legal methods. Data sources consist of primary legal materials, secondary legal materials and non-legal materials. The results showed that the implementation of fiduciary guarantees in motor vehicle financing agreements at PT. BFI Finance Gorontalo is in accordance with Law Number 42 of 1999 concerning Fiduciary Guarantees. Default by the debtor can result in the execution of fiduciary guarantees without having to obtain a court decision because the fiduciary guarantee certificate has the same executorial power as a court decision that has obtained permanent legal force, without having to wait for a court decision, execution can continue to be carried out. If the debtor or fiduciary giver fails the promise, the execution of the object that becomes the object can be done by executing the executable title. If in the implementation of fiduciary collateral execution the transfer of collateral occurs by the debtor, then the PT. BFI Finance Gorontalo can take legal action on accusations of embezzlement of collateral.
\end{abstract}

KEYWORDS: Legal Certainty, Default, Fiduciary

\section{INTRODUCTION}

In the context of Indonesia's economic development, of course, positively opening up good and large business opportunities for the community, this business opportunity is expected to encourage the macroeconomic sector to become more advanced so as to be able to improve the level of welfare of the Indonesian people as expected in the country's goals as stated in the opening of the Constitution NRI of 1945, namely improving the welfare of the Indonesian people.(Purnomo, 2016; Setyaningsih, 2015; Tyas \& Safitri, 2014) With the increasingly widespread business opportunities, which can't be dammed again, then the need for funds needed both by individual entrepreneurs and entrepreneurs who are members of a legal entity in developing their business and in improving the quality of their products, so that a satisfactory profit can be achieved and the level of need for other groups.(Aminuddin Ilmar, 2010; Manan, 2016; Susanty, 2017) 
In order to need these funds, now more and more people are establishing a financial institution which is engaged in providing funds or goods that will be used by other parties in developing their business.(Angkasa, 2016; Kairupan, 2017) Financing carried out by a financial institution, both a bank and a non-bank financial institution, can be intended for the purpose of production, distribution or consumption of goods and services.(Muktar, 2016; Widayati \& Mendari, 2019)

The definition of non-bank financial institutions can be seen in Article 1 number (4) of the Decree of the President of the Republic of Indonesia Number 61 of 1988 concerning Financing Institutions, non-bank financial institutions are business entities that carry out activities in the financial sector that directly or indirectly raise funds by issuing funds securities and distribute them into the community to finance the investment of companies. (Astuti, 2010; Febrianto \& Absori, 2019; Susanty, 2017) In Article 1 number 1 of the Republic of Indonesia Presidential Regulation Number 9 of 2009 Concerning the Financing Institution, it is stated that what is meant by a financial institution is a business entity conducting financing activities in the form of providing funds or capital goods.(Kambey, 2015; Saragih, 2019)

According to Presidential Decree of the Republic of Indonesia Number 61 of 1988 concerning Financing Institutions the business fields of the Financing Institution include consumer financing. The legal basis for this consumer financing agreement is an agreement between the parties based on the principle of freedom of contract, namely an agreement between the financial company as a creditor and the consumer as the debtor. (Jayati, 2011; Parrangan, 2019; Prasetyawati, 2012) Non-bank financial institutions that channel funds or provide financing (in the form of loans or credit) to debtors for the purpose of consumption of goods and services are called consumer finance companies. This is very much needed for companies engaged in any field both in terms of distribution, production and consumption.(Hartanto, 2011; Jayati, 2011)

As for the business sectors of the financial institution are leasing, securities trading, factoring, venture capital, consumer financing, and credit cards. In Indonesia, the legal basis of this financial institution does not yet have any provision that specifically regulates these financing activities, but these are agreements that arise in practice, made by parties related to each other in trade or relations other law.(Siombo, 2019; Soemitra, 2017) Therefore, as an in-nominat agreement based on Article 1319 of the Civil Code (hereinafter referred to as the Civil Code) then:

"All agreements, whether they have a special name or do not have a specific name, or that are not known by a certain name, are subject to the general rules contained in this chapter and the previous chapter"

Thus looking at Article 1319 of the Civil Code, the regulation on Consumer Finance (consumer finance) also needs to comply with the principles and legal provisions contained in the Civil Code, especially in book III on the Agreement.(Khair, 2017; Simatupang, 2020) Consumer finance becomes very important for a company because this can help their task in increasing sales of products or services. In addition, this becomes an important thing for consumers because consumer finance companies can help consumers to buy goods or services on credit.(Karinda, 2020; Siombo, 2019) 
The rise of various kinds of activities of financial institutions (finance) and banks (commercial and credit banks) that carry out financing for consumers (consumer finance), leasing, factoring, where they generally use the procedure for agreements that include there is a fiduciary guarantee for fiduciary collateral objects. (Purwanto, 2012; Wiebyantoro, 2015) The definition of fiduciary guarantee itself is a guarantee right on movable objects both tangible and intangible and immovable objects, especially buildings that cannot be encumbered by the security rights referred to in Law Number 4 of 1996 concerning Underwriting Rights which remain under the control of the giver fiduciary, as collateral for paying off certain debts, which gives priority position to the recipients of other creditors' fiduciary Guarantees.(Anggun, 2016; Sriono, 2019; Yani, 2020)

A simple practice in fiduciary collateral is that the debtor / party who has the goods submit financing to the creditor, then both parties agree to use a fiduciary guarantee on the debtor's property and make a notarial deed and then register it with the Fiduciary Registration Office. Creditors as fiduciary recipients will receive a fiduciary certificate, and a copy is given to the debtor.(Astuti, 2010) Consequently the debtor hands over to the creditor (credit provider) in a fiduciary manner. This means that the debtor as the owner on behalf of the goods becomes the fiduciary giver to the creditor who is in the position as the fiduciary recipient.(Adawiyah Nasution \& Ferry Susanto Limbong, 2020; Fathinah, 2019). Related to the imposition of fiduciary guarantees in consumer financing activities, it is necessary to pay attention to the provisions in Law No.42 of 1999 concerning Fiduciary Guarantees and Regulation of the Minister of Finance Number 130 / PMK.010 / 2012 concerning Registration of Fiduciary Guarantees for Financing Companies Conducting Consumer Financing for Motorized Vehicles by Loading Janiman Fiduciary.(Risnia, 2017; Sangeroki, 2020; Sipayung, 2019)

PT. BFI Finance Gorontalo is a finance company conducting business in the field of consumer finance (consumer finance), which focuses on motor vehicle loans. Financing activities are carried out through a system of lending which is paid by consumers in installments or periodically. At PT. BFI Finance Gorontalo consumer financing agreement is a debt and debt agreement between PT. BFI Finance Gorontalo with consumers by fiduciary delivery of goods in the sense of delivery of goods is carried out on trust. In practice at PT. BFI Finance Gorontalo conducts business activities as a financing company, found several obstacles / problems encountered. In connection with how to guarantee motor vehicle financing is inseparable from the occurrence of a risk that is the existence of consumers who default. Problems that have occurred in the implementation of financing agreements between creditors and debtors, especially those that occur at PT. BFI Finance Gorontalo is a default made by the debtor to the creditor, namely a default in credit payments. Bad credit can occur due to several factors including the debtor's economic situation which is more difficult so that it prevents the debtor to pay installments regularly and on time, as for the types of defaults undertaken by debtors of PT. BFI Finance Gorontalo is known as "overdue", Civil Code Article 1238.

Losses experienced by PT. BFI Finance Gorontalo has caused them to take steps to recover their losses, but many obstacles are experienced in the process, therefore the contract agreed between the two parties must meet the terms and conditions to minimize problems that occur in the future. 


\section{METHODOLOGY}

This study uses normative legal research methods. Relating to the type of normative legal research that is used as a reference, the approach used, the statute approach, and the statutory approach are used to examine all laws and regulations relating to consumer finance.(Barus, 2013; Diantha, 2016)

Legal materials used in this study include primary legal materials consisting of laws and regulations, which are related to consumer financing. Secondary legal material is all publications about law that are not official documents, among others, obtained from textbooks, journals, scholars' opinions, court decisions, the results of research reports and the results of seminars/workshops/symposiums conducted by experts associated with discussions on consumer finance. Non Legal Materials are legal materials that are closely related to primary legal materials and secondary legal materials, including non-legal textbooks (such as political books, management, etc.), language dictionaries, census data, company annual reports and general encyclopedias that are related with the study in this study. (Martono, 2010)

\section{RESULTS AND DISCUSSION}

\section{Legal consequences that occur, if (debtor) recipient of consumer financing do a default}

Defaults have very important consequences, it must be determined in advance whether the debtor has defaulted and if this is denied it must be proven. Determination of the time of the default is often not promised correctly, when the debtor is required to perform the achievements that have been promised. Regarding the time of default, it is regulated in Article 1238 of the Civil Code, which states that the debtor is negligent, if he has been issued with a warrant or with a similar deed that has been declared negligent, or for his own agreement, if this stipulates that the debtor will be considered negligent by the passage of time is stopped.

Based on this article, there are three ways to determine that the debtor is in default, namely: (a) With a warrant; (b) With a similar deed; (c) With the contents of the agreement stipulating negligence with the deadline in the agreement. If the debtor has defaulted it will have legal consequences for the parties to the agreement. The provisions of Article 1267 of the Civil Code state that: "the party to whom the agreement is not fulfilled, can choose whether he, if it is still being done, will force the other party to fulfill the agreement, or whether he will demand the cancellation of the agreement, accompanied by compensation for losses and interest".

According to Article 1267 of the Civil Code, defaults result in creditors being able to sue in the form of: (1) Fulfillment of achievement; (2) Termination of achievement; (3) Compensation; (4) Fulfillment of the agreement accompanied by compensation; (5) Termination of the agreement accompanied by compensation. 
Sanctions to debtors who default, namely (1) Paying the losses suffered by creditors or compensation; and (2) Cancellation of agreement.

In terms of form, the default (negligence / negligence) of a debtor can be divided into four types, namely: (1) Not doing what he is promised to do; (2) Carry out what was promised, but not as promised; (3) Doing what was promised but it was too late; and (4) Doing something which according to the agreement cannot be done. Determine what is meant by default in the financing agreement with the transfer of fiduciary ownership rights in PT. BFI Finance Gorontalo, can be seen from the rights and obligations of the parties. This is important, because the default itself arises because rights and obligations are not implemented.

One type of default is done by debtors of PT. BFI Finance Gorontalo is "overdue". The definition of "overdue" itself is the delay in the implementation of payment obligations at the time specified in the financing agreement. These late payments are classified into four categories, namely: (a) Overdue above 45 days but below 60 days; (b) Overdue above 60 days but below 90 days; (c) Overdue above 90 days but below 150 days; and (d) Overdue above 150 days. This overdue can be included in the category of default in the form of "doing but not on time / late", in this case the debtor will still pay the installment money but after the payment is due has passed.

\section{Execution procedures for object agreements which are charged with fiduciary guarantees in consumer financing agreements.}

Execution of the Fiduciary Guarantee is carried out by PT. BFI Finance Gorontalo after SKP (Order Withdrawal) is issued. PT. BFI Finance Gorontalo can execute without having to wait for a court decision, in carrying out the execution task of PT. BFI Finance Gorontalo participated in bringing a fiduciary guarantee certificate to be shown to the debtor with the aim of facilitating execution. And if the collateral is difficult to find or may have been transferred, PT. BFI Finance Gorontalo will take legal action by reporting to the authorities on the grounds of embezzlement of collateral.

At the time of signing of the financing agreement with fiduciary guarantees between PT. BFI Finance Gorontalo with the debtor, each party without exception shall be obliged to carry out and comply with the contents of the agreed financing agreement which in the agreement concerns the rights and obligations of the debtor and creditor stated in the terms of the financing agreement. The terms of this financing agreement constitute a unity and or are an inseparable part of the financing agreement.

According to Article 1234 of the Civil Code, a manifestation of an achievement, namely giving something, doing something, and not doing something. Sometimes the debtor's performance cannot be done as it should, this is due to two things:

a. Because of the debtor's mistake, either due to deliberate or due to negligence, it is called default.

b. Because the circumstances force, which is beyond the ability of the debtor, is called overmacht. 
The author agrees with what is done by PT. BFI Finance Gorontalo, the procedure for the occurrence of Fiduciary Guarantees has been done by making a fiduciary deed made by a notary who then registered with the Fiduciary Registration Office (KPF). Therefore the provisions contained in the Fiduciary Act can be enforced.

Sometimes the majority of fiduciary guarantees are made notary deed but not registered with the KPF, the provisions in the Fiduciary Act cannot be enforced, because the agreement is not a fiduciary agreement, but an ordinary agreement, therefore the creditor's position in the agreement is concurrent creditors. The provisions of the Fiduciary Law cannot be enforced, because the Fiduciary Law cannot be applied, so that the debt can be fulfilled, what is used is Article 1131 of the Civil Code, "The wealth of all material debts, both movable and immovable, both existing and new will be in the future, is a responsibility for all one's ties"

\section{CONCLUSION}

First, defaults result in creditors being able to sue in the form of: (1) Fulfillment of performance; (2) Termination of achievement; (3) Compensation; (4) Fulfillment of the agreement accompanied by compensation; (5) Termination of the agreement accompanied by compensation. Sanctions to debtors who default, namely (1) Paying the losses suffered by creditors or compensation; and (2) Cancellation of the agreement.

Second, the procedure for implementing fiduciary guarantees is carried out by registering with the Fiduciary Registration Office, leveling up is carried out by a notary in collaboration with PT. BFI Finance Gorontalo is stated in a fiduciary deed to be registered for the issuance of a Fiduciary Guarantee Certificate by the Ministry of Law and Human Rights of the Republic of Indonesia. This is done to strengthen the position of creditors if debtors defaulting can be easier to carry out collateral execution.

First, financing with fiduciary guarantees carried out should be based on good faith and if problems occur should be done amicably through peace, it is very regrettable if debtors default and transfer fiduciary guarantees, and make the legal process longer.

Second, based on the reality that often occurs in the implementation of financing agreements with fiduciary guarantees, namely the existence of defaults carried out by the debtor, the debtor should be required to provide additional guarantees to the finance company. Financing companies should be more selective in choosing debtor candidates.

\section{REFERENCCES}

Adawiyah Nasution, S. H., \& Ferry Susanto Limbong, S. H. (2020). TINJAUAN YURIDIS ATAS PELAKSANAAN JAMINAN FIDUSIA. PROSIDING SEMINAR NASIONAL HASIL PENELITIAN, 3(1), 1-10.

Aminuddin Ilmar, S. H. (2010). Hukum Penanaman Modal di Indonesia. Prenada Media. Anggun, W. P. (2016). Perlindungan Hukum bagi Penerima Fidusia atas Jaminan berupa Piutang berdasarkan Surat Daftar Piutang yang Dibuat oleh Pemberi Fidusia (Studi terhadap Pasal 9 Undang-Undang Nomor 42 Tahun 1999 tentang Jaminan Fidusia). Kumpulan Jurnal Mahasiswa Fakultas Hukum. 
Angkasa, N. A. N. (2016). KENDALA PENERAPAN PEMBIAYAAN LEASING UNTUK PEMENUHAN KEBUTUHAN MASYARAKAT. DERIVATIF: Jurnal Manajemen, 10(1).

Astuti, I. D. (2010). Perjanjian pembiayaan dalam bentuk leasing dengan jaminan fidusia dalam perspektif peraturan presiden nomor 9 tahun 2009 tentang lembaga pembiayaan pada PT. Astra Credit Companies Surakarta.

Barus, Z. (2013). Analisis Filosofis Tentang Peta Konseptual Penelitian Hukum Normatif Dan Penelitian Hukum Sosiologis. Jurnal Dinamika Hukum, 13(2), 307-318.

Diantha, I. M. P. (2016). Metodologi penelitian hukum normatif dalam justifikasi teori hukum. Prenada Media.

Fathinah, I. (2019). Akibat Hukum Menjual Objek Jaminan Fidusia Oleh Dibitur Kepada Pihak Ketiga Dalam Perjanjian Pembiayaan Konsumen (Studi Di PT. Astra Sedaya Finance Medan) [PhD Thesis].

Febrianto, F., \& Absori, D. (2019). Perlindungan Hukum Konsumen Pada Perusahaan Pembiayaan Dalam Pemberian Kredit Di Kartasura [PhD Thesis]. Universitas Muhammadiyah Surakarta.

Hartanto, S. S. (2011). JAMINAN DAN PEMBIAYAAN KONSUMEN STUDI TENTANG PERLINDUNGAN HUKUM BAGI PEMBERI JAMINAN (DEBITUR) DALAM PERJANJIAN PEMBIAYAAN KONSUMEN KENDARAAN BERMOTOR (Studi Kasus di PT. FIF Surakarta) [PhD Thesis]. Universitas Muhammadiyah Surakarta.

Jayati, T. D. (2011). JAMINAN DAN PEMBIAYAAN KONSUMEN (Studi tentang Aspek Jaminan dalam Pelaksanaan Perjanjian Pembiayaan Konsumen di PT. BFI FINANCE INDONESIA Tbk, Solo) [PhD Thesis]. Universitas Muhammadiyah Surakarta.

Kairupan, A. G. (2017). TINJAUAN YURIDIS TERHADAP MANFAAT LEMBAGA PEMBIAYAAN SEWA GUNA USAHA (LEASING) PADA BISNIS MODERN PADA ERA GLOBAL. LEX ET SOCIETATIS, 5(3).

Kambey, S. F. (2015). Perlindungan Hukum Terhadap Perusahaan Pembiayaan Dalam Perjanjian Leasing [PhD Thesis]. Tadulako University.

Karinda, R. A. (2020). PERLINDUNGAN HUKUM TERHADAP KONSUMEN DALAM BISNIS PEMBIAYAAN MENURUT UNDANG-UNDANG NOMOR 8 TAHUN 1999. LEX PRIVATUM, 8(4).

Khair, U. (2017). Analisis Yuridis Perjanjian Pembiayaan Konsumen Dan Akibat Hukum Jika Terjadi Wanprestasi Dalam Perjanjian Pembiayaan Konsumen Di Indonesia. JCH (Jurnal Cendekia Hukum), 3(1), 32-45.

Manan, D. A. (2016). Peranan Hukum dalam Pembanguna Ekonomi. Kencana.

Martono, N. (2010). Metode penelitian kuantitatif: Analisis Isi dan Analisis Data Sekunder (sampel halaman gratis). RajaGrafindo Persada.

Muktar, B. (2016). Bank dan Lembaga Keuangan Lain. Prenada Media. 
Parrangan, G. D. (2019). FUNGSI OTORITAS JASA KEUANGAN DALAMMELINDUNGI KEPENTINGAN KONSUMEN DALAM PERJANJIAN PEMBIAYAAN. LEX ADMINISTRATUM, 6(4).

Prasetyawati, E. (2012). Perlindungan Hukum Terhadap Para Pihak Dalam Pembiayaan Konsumen. DiH: Jurnal Ilmu Hukum, 8(16).

Purnomo, R. A. (2016). Ekonomi Kreatif Pilar Pembangunan Indonesia. Ziyad Visi Media.

Purwanto, P. (2012). BEBERAPA PERMASALAHAN PERJANJIAN PEMBIAYAAN KONSUMEN DENGAN JAMINAN FIDUSIA. Jurnal Rechts Vinding: Media Pembinaan Hukum Nasional, 1(2), 199-214.

Risnia, D. (2017). ANALISIS PENERAPAN SANKSI TINDAK PIDANA KORUPSI TERHADAP BADAN HUKUM LEASING YANG TIDAK MELAKSANAKAN KEWAJIBAN PENDAFTARAN JAMINAN FIDUSIA.

Sangeroki, A. B. (2020). PERLINDUNGAN TERHADAP KONSUMEN DALAM KONTRAK JUAL BELI KENDARAAN BERMOTOR SECARA ANGSURAN. LEX PRIVATUM, $8(3)$.

Saragih, J. P. (2019). TANTANGAN PERUSAHAAN PEMBIAYAAN DALAM PERSAINGAN PASAR INDUSTRI JASA KEUANGAN DI INDONESIA. Peran Industri Keuangan Non Bank Terhadap Perekonomian Nasional, 63.

Setyaningsih, E. D. (2015). Peluang dan Tantangan Usaha Mikro Kecil dan Menengah dalam Menghadapi Masyarakat Ekonomi Asean. Moneter-Jurnal Akuntansi Dan Keuangan, 2(2).

Simatupang, Y. F. (2020). Tanggung Jawab Perusahaan Pembiayaan Terhadap Hilangnya Objek Perjanjian (Studi Putusan No. 88/Pdt. G/2015/PN. Mdn) [PhD Thesis]. Universitas Medan Area.

Siombo, M. R. (2019). Lembaga Pembiayaan dalam Perspektif Hukum. Penerbit Unika Atma Jaya Jakarta.

Sipayung, I. M. (2019). Rekonstruksi Hukum Eksekusi Jaminan Fidusia Yang Memiliki Kekuatan Eksekutorial Dengan Berbasis Keadilan [PhD Thesis]. Universitas Islam Sultan Agung.

Soemitra, A. (2017). Bank \& Lembaga Keuangan Syariah. Prenada Media.

Sriono, S. (2019). Tanggung jawab pemberi fidusia terhadap benda jaminan fidusia dalam perjanjian kredit. Jurnal Ilmiah Advokasi, 7(2), 149-159.

Susanty, A. P. (2017). Perlindungan Hukum Terhadap Kelangsungan Usaha Mikro, Kecil, dan Menengah Atas Pemberlakuan Masyarakat Ekonomi Asean. Jurnal Hukum Respublica, 16(2), 313-332.

Tyas, A. A. W. P., \& Safitri, V. I. (2014). Penguatan sektor UMKM sebagai strategi menghadapi MEA 2015. Jurnal Ekonomi Universitas Esa Unggul, 5(1), 17895.

Widayati, R., \& Mendari, W. E. (2019). Upaya Penanganan Kredit Bermasalah Pada Bank Nagari Cabang Utama Padang. 
Wiebyantoro, D. (2015). PERLINDUNGAN HUKUM TERHADAP KONSUMEN ATAS SENGKETA JAMINAN FIDUSIA DITINJAU DARI UNDANGUNDANG JAMINAN FIDUSIA DAN UNDANG-UNDANG PERLINDUNGAN KONSUMEN (Studi Kasus pada PT. Adira Finance Cabang Kudus) [PhD Thesis]. Universitas Pembangunan Nasional Veteran Jakarta.

Yani, S. (2020). Perlindungan Hukum Terhadap Debitur Pada Perjanjian Pembiayaan Konsumen Dengan Pembebanan Jaminan Fidusia. UNES Law Review, 2(3), 299-320. 